\title{
Effect of total volume replenishment of massive obstetric blood loss on the frequency and severity of multiple organ dysfunction syndrome
}

\author{
Sedinkin Vladyslav, Klygunenko Olena
}

State Establishment "Dnipropetrovsk Medical Academy of Health Ministry of Ukraine", Department of Anesthesiology, Intensive Care and Emergency Medicine FPE, Dnipropetrovsk, Ukraine

\section{Background}

- Obstetrical hemorrhage remains a leading cause of maternal mortality worldwide. The use of fibrinogen concentrates and prothrombin complex concentrates has emerged as new potential alternative treatment strategies with improved safety profiles [1].

- The uses of PCC have advantages over allogeneic plasma in its rapid availability, restoration of target factor(s), lower risks for volume overload and reduces the requirement for blood component therapy and the associated complications [2].

The Goal of our Study: The Aim to evaluate the effect of total replenishment of massive obstetric blood loss in the frequency and severity of clinical manifestations of MODS.

\begin{abstract}
Material and Methods
Having agreed with the local Ethics Committee and obtained the informed consents, 68 women (whose delivery or early postpartum period was complicated by acute severe hemorrhage with blood volume (BV) deficit of 44-52\%) were examined. Patients were randomized into 2 groups depending on the characteristics of the BV replenishment. Both groups were similar in relation to age, height, gestation term, blood loss volume $(2621 \pm 613 \mathrm{ml})$ (Table 1). In 1 group $(n=30)$ BV replenishment performed according to Ukrainian national protocol (relation between erythrocytes, FFP, and platelet (if necessary) is 1:1:1). In 2 group ( $n=38$ ) 1500 IU of Prothrombin Complex Concentrate (PCC - Octaplex®, Octapharma PPGmbH, Austria) was added to therapy. Were assessed: the number of red blood cells, hemoglobin, hematocrit, standard coagulation, $\mathrm{SaO}_{2}$, liver-kidney complex. Clinical signs of MODS are accounted for myocardial insufficiency (frequency and duration of vasopressor support); respiratory dysfunction (frequency and duration of mechanical ventilation); acute kidney injury (frequency and duration of renal replacement therapy), gastrointestinal dysfunction (frequency and duration of the enteroparesis). The time points: $1,3,5,7,10,14$ and 28 days after delivery.
\end{abstract}

\begin{tabular}{|c|c|c|c|c|c|c|c|}
\hline Group & $\mathbf{n}$ & $\begin{array}{l}\text { Age, } \\
\text { years }\end{array}$ & $\begin{array}{c}\text { Body } \\
\text { weight } \\
\text { kg }\end{array}$ & $\begin{array}{l}\text { Height } \\
\text { cm }\end{array}$ & $\begin{array}{l}\text { Gestatio } \\
\text { n weeks }\end{array}$ & $\begin{array}{c}\text { Blood } \\
\text { loss } \\
\text { volume, } \\
\text { ml }\end{array}$ & $\begin{array}{l}\text { Blood loss } \\
\text { volume, \% to } \\
\text { circulating } \\
\text { blood volume }\end{array}$ \\
\hline $\begin{array}{c}\text { Contr } \\
\text { ol }\end{array}$ & 30 & $\begin{array}{c}28.5 \\
\pm \\
7.1\end{array}$ & $\begin{array}{c}71.2 \\
\pm \\
8.3\end{array}$ & $\begin{array}{c}165.3 \\
\pm \\
4,8\end{array}$ & $\begin{array}{c}36.8 \pm \\
2.5\end{array}$ & $\begin{array}{c}2535 \\
\pm \\
604\end{array}$ & $\begin{array}{c}48.2 \pm \\
4.2\end{array}$ \\
\hline PCC & 38 & $\begin{array}{c}30.7 \\
\pm \\
5.5\end{array}$ & $\begin{array}{c}69.3 \\
\pm \\
6.2\end{array}$ & $\begin{array}{c}163.5 \\
\pm \\
5.6\end{array}$ & $\begin{array}{c}37.7 \pm \\
3.1\end{array}$ & $\begin{array}{c}2706 \\
\pm \\
627\end{array}$ & $\begin{array}{c}51.1 \pm \\
3.5\end{array}$ \\
\hline
\end{tabular}

Results and Discussion

Analysis showed that use of PCC reduced total infusiontransfusion volume by $24.5 \%(1300 \mathrm{ml})$. Comparative analysis of the frequency and severity of clinical manifestations of MODS is presented in Table 2. Patients 2 group had decreased frequency and duration of vasopressor support, frequency and duration of mechanical ventilation, had reduced the number of patients requiring renal replacement therapy, and it duration. The frequency gastrointestinal dysfunction reduced more than twice. This provided a significant reduction in the duration of stay in the ICU from 14.1 \pm 1.7 (1 group) to $7.8 \pm 2.1$ days ( 2 group).

Table 2. The frequency and severity of MODS in the comparison groups

\begin{tabular}{|l|l|l|}
\multicolumn{1}{c|}{ MODS signs } & Control, (n=30) & PCC, (n=38) \\
\hline Myocardial insufficiency, number (\%) & $11(36.7 \%)$ & $4(10.5 \%)$ \\
\hline - duration of vasopressor support, days & 3.3 & 2.1 \\
\hline Respiratory dysfunction, number (\%) & $7(23.3 \%)$ & $2(5.3 \%)$ \\
\hline - duration of mechanical ventilation, days & 3.4 & 2.5 \\
\hline Acute kidney injury, number $(\%)$ & $21(70 \%)$ & $14(36.8 \%)$ \\
\hline - duration of renal replacement therapy, days & 4.3 & 2.8 \\
\hline Gastrointestinal dysfunction, number $(\%)$ & $15(50 \%)$ & $9(23.7 \%)$ \\
\hline - duration of the enteroparesis, days & 5.1 & 2.9
\end{tabular}

\section{Conclusion}

Reducing the total volume of infusion-transfusion therapy provides a significant decrease in frequency of clinical signs of multiple organ dysfunction syndrome and reduces the duration of stay in the ICU

\section{References}

1. Pacheco L.D., Saade G.R., Costantine M.M. et al. An update on the use of massive transfusion protocols in obstetrics. American Journal of Obstetrics and Gynecology 2016, 214 (3): 340-4 DOI: http://dx.doi.org/10.1016/j.ajog.2015.08.068 